\title{
COMPARISSION OF DEVELOPMENT LEVELS BETWEEN RURAL AND INDUSTRIAL AREAS IN THE STATE OF SÃO PAULO
}

João Eustachio

University of São Paulo (FEA-RP/USP)

Marlon Fernandes Rodrigues Alves

University of São Paulo (FEA-RP/USP)

Federal Institute of Education, Science and Technology of São Paulo

Bruno Garcia de Oliveira

University of São Paulo (FEA-RP/USP)

Caroline Krüger

University of São Paulo (FEA-RP/USP)

Adriana Cristina Ferreira Caldana

University of São Paulo (FEA-RP/USP)

Dante Pinheiro Martinelli

University of São Paulo (FEA-RP/USP)

\begin{abstract}
Verifying the level of development of localities is strategic because it allows public management to make correct decisions. In this way, the goal of this paper is to compare the levels of development between areas that are typically rural to the typically industrial ones of the state of São Paulo and check which one is more developed. To achieve the results, it was used the method of factor analysis, with variables of several dimensions to build indicators. The factor analysis returns three factors. According to its characteristics they were considered indicators of rural development, urban development and industrial and services development. Clusters of similar areas also have been set up according to those three indicators. The results showed that the cluster of typically rural areas may present higher levels of development when compared to the industrial ones.
\end{abstract}

Keywords: Development Indicators. Local Development. Rural Development. Public Policies.

Resumo: Verificar o nível de desenvolvimento das localidades é estratégico porque permite que a gestão pública tome decisões corretas. Desta forma, o objetivo deste trabalho é comparar os níveis de desenvolvimento entre áreas que são tipicamente rurais com as tipicamente industriais do estado de São Paulo. Para alcançar os resultados, é utilizado o método de análise fatorial, com variáveis de diversas dimensões para a construção de indicadores de desenvolvimento. A análise fatorial retorna três fatores os quais são considerados indicadores. Assim, de acordo com suas características, foram considerados indicadores de desenvolvimento rural, desenvolvimento urbano e desenvolvimento industrial e de serviços. Clusters de regiões similares também são configurados de acordo com estes três indicadores. Os resultados mostram que o cluster de áreas tipicamente rurais pode apresentar níveis de desenvolvimento mais elevados quando comparados ao cluster de áreas tipicamente industriais e de serviços.

Palavras-chave: Indicadores de desenvolvimento. Desenvolvimento local. Desenvolvimento Rural. Políticas Públicas.

Área ABEIN: 4.5 Inovação, desenvolvimento e sustentabilidade.

Classificação JEL: R1 


\title{
COMPARISSION OF DEVELOPMENT LEVELS BETWEEN RURAL AND INDUSTRIAL AREAS IN THE STATE OF SÃO PAULO
}

\begin{abstract}
Verifying the level of development of localities is strategic because it allows public management to make correct decisions. In this way, the goal of this paper is to compare the levels of development between areas that are typically rural to the typically industrial ones of the state of São Paulo and check which one is more developed. To achieve the results, it was used the method of factor analysis, with variables of several dimensions to build indicators. The factor analysis returns three factors. According to its characteristics they were considered indicators of rural development, urban development and industrial and services development. Clusters of similar areas also have been set up according to those three indicators. The results showed that the cluster of typically rural areas may present higher levels of development when compared to the industrial ones.
\end{abstract}

Keywords: Development Indicators. Local Development. Rural Development. Public Policies.

\section{INTRODUCTION}

In an unstable environment, whose complete understanding of the causal relationships for making the best decision is impractical, analytic routines act by reducing the level of complexity and increasing cognitive efficiency (MARCH; SIMON, 1958). In this way, the understanding of the development phenomenon of local development in a qualitative way is enriching and widely used by renowned authors who contribute important detailed studies to the academic world. In addition to these qualitative studies, it is equally important to understand local development from a quantitative perspective, verifying the level of development of localities so that it is possible to guide public managers, especially in relation to the main strengths and weaknesses present in each locality. Like this, it is possible to formulate and follow up these policies in order to know how localities have developed over time.

It is important (and convenient) to assume that local development is a complex phenomenon (WONG, 2002). That is, there are several variables of different dimensions (economic, social, environmental and political) that, in an integrated way, lead to development. Thus, it is necessary to use techniques that take into account the complexity of the local development. For this, Bertalanffy (1968) shows in his book "General system theory: foundations, development, applications" that the statistical technique of factor analysis is a systemic way of data analysis, since it seeks to understand the correlation of variables that do not necessarily belong to the same dimension.

There is a great interest both in the public and private spheres in order to understand issues related to local development so that it is possible to stimulate economic activity and, at the same time, to develop social issues of certain localities (LLORENS, 2001). For this, it is necessary to establish a tool that integrates dimensions and contributes to the control of the public policy cycle (HOWLETT; RAMESH; PERL, 1995; SECCHI, 2009). In this sense, the studies in strategy contribute, when dedicating itself to the choices that an organization assumes for its evolution in a competitive environment. Such choices are interrelated in order to allow them to adapt to the environment and even to shape it (AUGIER; TEECE, 2008).

The objective of this study is to check if the typically rural areas of the state of São Paulo can present higher levels of development compared to the typically industrial ones. In order to do so, this study will use indicators formed from the exploratory factorial analysis technique, involving not only economic, but also social, demographic, geographic and energy- 
related variables, using as reference the studies performed by Barbosa (2013), Ilha et al. (2008) and Perobelli et al. (1999).

Once the regional development indicators are generated, groupings of the regions of government will be developed with the intention of understanding the homogeneities presented by the identified indicators (BARBOSA, 2013). After that, it was possible to analyze the particularities of each group and also the observations in an individual way.

\section{LITERATURE REVIEW}

Local development has become one of the main research guidelines in recent decades. However, it is a controversial subject, possessing diverse concepts and assuming diverse characteristics and adjectives over time.

Fragoso (2005) says that local development is linked to the issue of population expressing the vision of the future for a given region, considering an open and flexible vision. In this context, the geographic question is no longer an obstacle for development to take place, making it possible to acquire flexible aspects, improving the quality of life and increasing levels of self-confidence and organization of a locality. This improvement in the quality of life to reach development happens due to a participatory process, involving the social actors of a given region (GRZESZCZESZYN; MACHADO, 2010; OLIVEIRA; MARTINS; VAZ; CALDAS, 2010; MARTINEZ, 2013).

Although complementary, the concepts of development and economic growth are distinct and often permeate the concepts of regional development over time. Growth is related to the economic dimension, while development encompasses other dimensions related to raising the standard of living and well-being of the population, thus incorporating other variables related to other dimensions such as social, cultural, environmental and political (ALBUQUERQUE, 1998; OLIVARES; DALCOL, 2010).

Therefore it is clear that the concept of development has acquired characteristics that are far-fetched over time, incorporating issues not only economic but also characteristics of sustainable development, adding the social and environmental dimensions (LLORENS, 2001). Thus, local development strategies gradually became more holistic, aimed at "restructuring the productive system, increasing local employment and improving the standard of living of the population" (OLIVEIRA; LIMA, 2003).

Regarding the definition, local development can be defined as an endogenous process that occurs in territorial units, being able to contribute to the economic growth and the quality of life of the civil society of a given region. The regional development, therefore, does not only exist on an economic perspective, linked to competitiveness (MARTINELLI; JOYAL, 2004), but also seeks to generate a social change at local level, contributing to the development of capacities and specific potentialities (MARTINS; VAZ; CALDAS, 2010).

The classic theories about regional development lead to the idea of the existence of a driving force that is influenced by economic activities. In this sense, the author criticizes the classic theories and the fact that they serve as a foundation for economic policies, leaving aside the fundamental sectors of local society. In this way, the author reinforces that regional development must be carried out with a focus on the participation of internal actors (MARTINS; VAZ; CALDAS, 2010).

This issue is also intrinsically linked to development strategies (AUGIER; TEECE, 2008; SACHS, 1986) To that end, Sachs (1986) introduces the issue of ecodevelopment, mentioning that there are five dimensions in which regional development strategies must be linked: social sustainability, economic sustainability, ecological sustainability, spatial sustainability and cultural sustainability. 
According to Mattos (2008), the economic dimension is due to the qualities that make local entrepreneurs use the means and production in an efficient way to guarantee their competitiveness. In relation to the socio-cultural dimension, the author points out the interaction between economic and social agents in a way that integrates with local institutions, forming a deep system of relations, which end up incorporating the values of society to the development process. The political dimension in this context is materialized through local initiatives, enabling the creation of a local environment that encourages production and strengthens development.

Therefore, for some authors, the question of development occurs through a process of transformation, generating improvements in income and, above all, the development of social structures. It also involves changes in the production mode, causing technological changes in the production processes, generating a greater supply of goods, services and improving the income distribution between the people (FURTADO, 2000; HADDAD, 2009).

\section{METHOD}

In order to address the objective of check if the typically rural areas of the state of São Paulo can present higher levels of development compared to the typically industrial ones, it was performed a quantitative approach using secondary data based. Through an analysis in relation to the bibliography that seeks to develop regional development indicators using the factorial analysis technique, 17 variables were selected that directly impact regional development according to authors who have already carried out similar studies (BARBOSA, 2013; ILHA et al., 2008; PEROBELLI et al., 1999).

Those 17 variables (Table 1) are available in the Data System and the Brazilian Institute of Geography and Statistics (INSTITUTO BRASILEIRO DE GEOGRAFIA E ESTATÍSITICA (IBGE), 2016). The study was carried out taking into the 43 Administrative Areas of State of São Paulo. In order to solve the question of units of measurement and different scales among variables, each variable was transformed into a standard score (Z-scores) (FÁVERO et. al, 2009). Thus, to proceed with the research, the database was prepared in matrix format, organized in such a way that the lines are represented by the Regions of Government of the State of São Paulo and the columns by the 17 variables presented in the previous item.

Once the matrix was established, the method selected to create regional development indicators was factorial analysis and cluster analysis and was developed following steps suggested by Fávero et. al (2009). First, factorial analysis was made in order to create indicators of development. Then, cluster analysis allowed to organize those indicators into homogeneous clusters as a function of the degree of dissimilarity between the individuals treated in the analysis, based on predetermined variables (LATTIN et al., 2011; FÁVERO et al., 2009). The statistical software IBM SPSS Statistics 22 was used to compute the analyzes.

\section{RESULTS AND DISCUSSIONS}

The extraction method used was the principal components method, through Varimax rotation and Kaiser normalization. After the rotation was converged in four iterations, three components were obtained: F1, F2 and F3, which represent respectively 53.34\%, $14.50 \%$ and $13.65 \%$ of the total variance of the data. Together, the three components extracted explain $81.5 \%$ of the total variance.

According to the TABLE 1, the Factor 1 shows high levels of correlation with the variables " Participation of Services in the GDP ", " Participation of Industry in the GDP ", "Number of graduated students in 2013", " Electricity consumption (market and services).", " Electricity consumption (Industry)", " Nursery registrations", " GDP "and "Population ". In order to clarify, Factor 1 will be renamed "Industrial and Services Development Level". 
Factor 2, in turn, shows a high degree of correlation with the variables "Level of Urbanization", " School enrollment rate of the population aged 15 to 17 years " and inversely correlated with " Number of inhabitants per vehicle " and " Mortality rate of the population between 15 and 34 years". For those reasons, Factor 2 will be renamed as "Urban Development Level".

Finally, Factor 3 presents a high degree of correlation with variables related to agriculture as " Participation of Agriculture in the GDP ", "Size of the Area" and "Electricity consumption (Agriculture)". Thus, it was decided to rename Factor 3 as "Rural Development Level".

TABLE 1. Matrix of rotated components.

\begin{tabular}{|c|c|c|c|}
\hline \multirow[b]{2}{*}{ Variables } & \multicolumn{3}{|c|}{ Factor Scores } \\
\hline & Factor 1 & Factor 2 & Factor 3 \\
\hline Participation of Agriculture in the GDP & & & ,932 \\
\hline Participation of Services in the GDP & ,990 & & \\
\hline Participation of Industry in the GDP & ,991 & & \\
\hline Size of the area & & & ,768 \\
\hline Number of graduated students in 2013. & ,990 & & \\
\hline Electricity consumption (market and services). & ,991 & & \\
\hline Electricity consumption (Industry) & ,908 & & \\
\hline Electricity consumption (Agriculture) & & &, $\mathbf{7 6 3}$ \\
\hline Electricity consumption (Total) & ,992 & & \\
\hline Level of Urbanization & & ,724 & \\
\hline \multicolumn{4}{|l|}{ Aging index } \\
\hline Nursery registrations & ,991 & & \\
\hline Number of inhabitants per vehicle & &,- 897 & \\
\hline$\overline{\text { GDP }}$ & ,992 & & \\
\hline Population & ,993 & & \\
\hline School enrollment rate of the population aged 15 to 17 years & & ,656 & \\
\hline Mortality rate of the population between 15 and 34 years & &,- 695 & \\
\hline
\end{tabular}

Once the rotating component matrix was calculated, the analysis was expanded in order to observe the value of each component in relation to each Government Region of the State of São Paulo. These generated components were renamed as development level and now integrate three new columns, generating the three indicators which were widely used both for the establishment of development rankings and to generate groupings of similar regions: (1) Indicator of development of industries and services; (2) indicator of urban development; and (3) rural development indicator.

After obtaining the three development indicators already reported, the cluster analysis was applied, obtaining the three distinct clusters. The clusters were formed according to the values of the three indicators, in relation to each administrative area. Thus, government regions with high values in the indicator "level of industrial development and services" were allocated in Cluster I. Similarly, the regions of government that presented high values in the indicator "level of agricultural development" appear in cluster II. It is important to emphasize that the Metropolitan Region of the State of São Paulo was characterized as an outlier, presenting characteristics that disrupt both Group I and Group II. 


\subsection{Cluster Analysis.}

To perform cluster analyzes, two-dimensional graphs were elaborated in order to facilitate the understanding of how the groups are arranged according to the three development indicators. The evidence of distinction between clusters occurs when scatter plots are analyzed where one of the axes is the level of agricultural development. In this sense, FIGURES 3 clearly show this information.

FIGURE 1. Observations between level of urbanization or industrial/services and agricultural development.
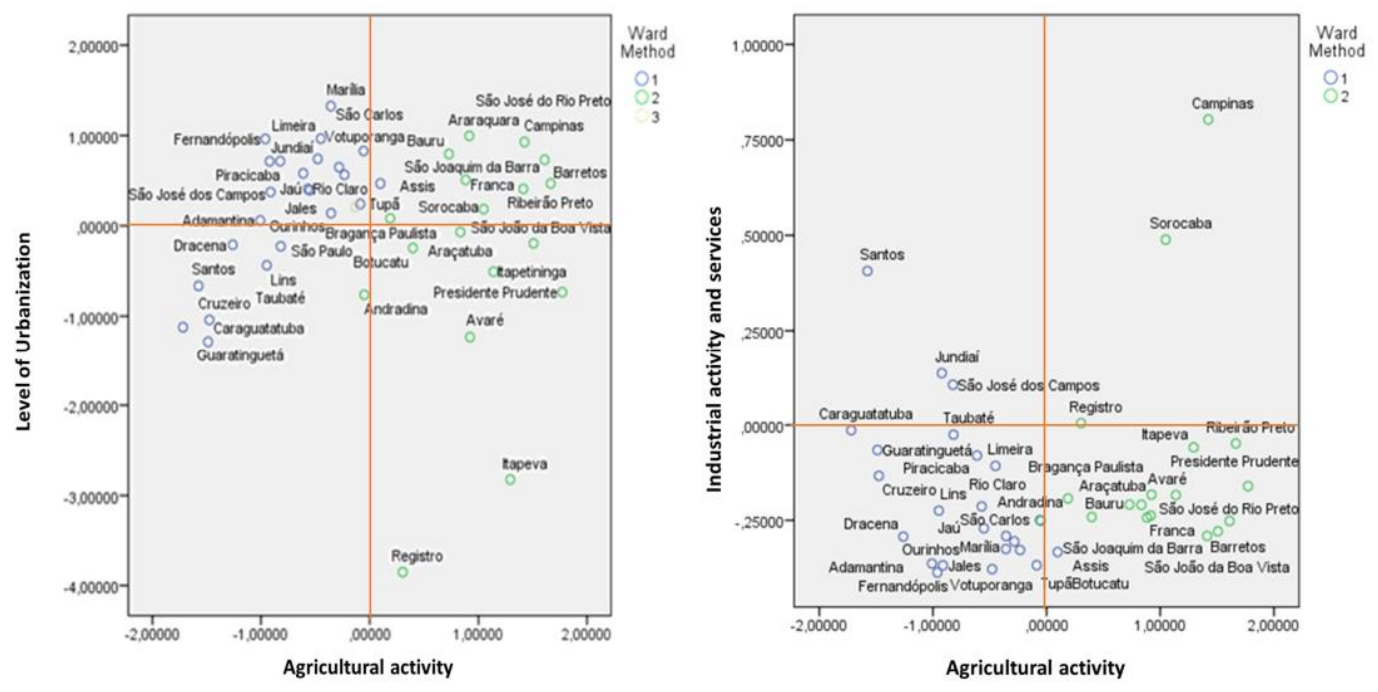

Source: Research Data - SPSS output.

In the first graph of FIGURE 1, where one of the axis is represented by the indicator of agricultural development and that of ordinates reflects the level of urban development, it is clear that there are both regions of low government and regions with high levels of agricultural development.

The indicators responsible for defining whether a region of government belongs to cluster 1 or cluster 2 are indicators of the level of industrial development / services ( first graph FIGURE 1) in in combination with the agricultural development indicator (second graph FIGURE 1):

- Cluster 1: It presents high indicators of industrial development / services and low agricultural development.

Cluster 2: In general, it presents low indicators of industrial development / services and high levels of agricultural development.

\subsection{Integrated Analysis: Elaboration of a ranking of development.}

Once the three development indicators are produced, it is interesting to rank each indicator in order to understand the level of development of the administrative are in order to verify if the most developed regions belong to cluster 1 (regions with a high level of industrial development / Services) or belong to group 2 (regions with high level of agricultural development).

Was made a ranking of the 10 government regions that presented the highest indicator of industrial development and service. It is important to note that in this ranking the position of the metropolitan region of the State of São Paulo, which is characterized in the analysis as an 
outlier and, for this reason, ends up presenting this indicator markedly greater than the second placed of the ranking (Campinas).

Although the metropolitan region of the State of São Paulo presents a value of 0.21 in the urban development indicator and -0.13 in the agricultural development indicator, it presents a high level of industrial development /services (approximately 6.2). This configuration explains why this observation has set up a new cluster, indicating that it is an outlier.

It is also noted in the ranking of TABLE 2 that the diversity of clusters, involving both regions of government that have high levels of industrial development / services and regions with high levels of agricultural development.

TABLE 2. Ranking of government regions with the highest indicators of industrial development/services.

\begin{tabular}{|c|c|c|c|c|c|}
\hline Ranking & Administrative Areas & $\begin{array}{c}\text { Industrial } \\
\text { Development } \\
\text { /services. }\end{array}$ & $\begin{array}{c}\text { Urban } \\
\text { Development }\end{array}$ & $\begin{array}{l}\text { Agriculture } \\
\text { Development }\end{array}$ & Cluster \\
\hline $\mathbf{1}^{\mathbf{0}}$ & São Paulo & 6,22 & 0,21 & $-0,13$ & 3 \\
\hline $2^{\circ}$ & Campinas & 0,80 & 0,93 & 1,42 & 2 \\
\hline $3^{\circ}$ & Sorocaba & 0,49 & 0,18 & 1,05 & 2 \\
\hline $4^{\circ}$ & Santos & 0,41 & $-0,67$ & $-1,58$ & 1 \\
\hline $5^{\circ}$ & Jundiaí & 0,14 & 0,71 & $-0,92$ & 1 \\
\hline $6^{0}$ & São José dos Campos & 0,11 & 0,71 & $-0,82$ & 1 \\
\hline $7^{\circ}$ & Registro & 0,01 & $-3,85$ & 0,30 & 2 \\
\hline $8^{\circ}$ & Caraguatatuba & $-0,01$ & $-1,12$ & $-1,72$ & 1 \\
\hline $9^{\circ}$ & Taubaté & $-0,03$ & $-0,23$ & $-0,82$ & 1 \\
\hline $10^{\circ}$ & Ribeirão Preto & $-0,05$ & 0,47 & 1,67 & 2 \\
\hline
\end{tabular}

Source: Research Data - SPSS output.

The question of diversity in the ranking by the indicator of industrial development / services no longer occurs in the ranking of the indicator of agricultural development (TABLE $3)$. In relation to the ten first places, all the regions of government are typically agricultural regions, belonging, therefore, to the Cluster 2.

TABLE 3. Ranking of government regions with the highest indicators of agricultural development.

\begin{tabular}{llcc|c|c}
\hline Ranking & Administrative Areas & $\begin{array}{c}\text { Industrial } \\
\text { Development } \\
\text { /services. }\end{array}$ & $\begin{array}{c}\text { Urban } \\
\text { Development }\end{array}$ & $\begin{array}{c}\text { Agriculture } \\
\text { Development }\end{array}$ & Cluster \\
\hline $\mathbf{1}^{\mathbf{o}}$ & Presidente Prudente & $-0,16$ & $-0,74$ & 1,77 & 2 \\
\hline $\mathbf{2}^{\mathbf{o}}$ & Ribeirão Preto & $-0,05$ & 0,47 & 1,67 & 2 \\
\hline $\mathbf{3}^{\mathbf{0}}$ & São José do Rio Preto & $-0,25$ & 0,73 & 1,61 & 2 \\
\hline $\mathbf{4}^{\mathbf{o}}$ & São João da Boa Vista & $-0,28$ & $-0,20$ & 1,51 & 2 \\
\hline $\mathbf{5}^{\mathbf{0}}$ & Campinas & 0,80 & 0,93 & 1,42 & 2 \\
\hline $\mathbf{6}^{\mathbf{0}}$ & Barretos & $-0,29$ & 0,41 & 1,41 & 2 \\
\hline $\mathbf{7}^{\mathbf{0}}$ & Itapeva & $-0,06$ & $-2,82$ & 1,29 & 2 \\
\hline $\mathbf{8}^{\mathbf{o}}$ & Itapetininga & $-0,18$ & $-0,51$ & 1,14 & 2 \\
\hline $\mathbf{9}^{\mathbf{0}}$ & Sorocaba & 0,49 & 0,18 & 1,05 & 2 \\
\hline $\mathbf{1 0}^{\mathbf{o}}$ & Avaré & $-0,18$ & $-1,23$ & 0,92 & 2 \\
\hline
\end{tabular}

Source: Research Data - SPSS output. 
Moreover, the arithmetic mean of local development indicator was evaluated for each cluster. In this sense, Cluster I, II e III have the following arithmetic means, respectively: -0,24, 0,2 e 2,10. These results might indicate Cluster II, which containing predominantly rural government regions, is more developed than clusters with predominantly industrial regions, if this analysis not consider Cluster III (compound by outlier São Paulo city).

\section{CONCLUSIONS}

This work addressed the issue of local development through the use of indicators using the statistical technique of multivariate data analysis called exploratory factorial analysis. The use of this technique sought to summarize the variables in order to reduce the complexity and variety of the problem through attenuators (BEER, 1985), which were treated in this article as indicators of local development (FÁVERO et al., 2009).

Factor analysis, in fact, contributed to analyze the research problem in a systemic way (BERTALANFFY, 1968), showing that it is possible to have a correlation between variables of different dimensions (FÁVERO et al., 2009) in order to help decision making Public policy cycle (HOWLETT; RAMESH; PERL, 1995; SECCHI, 2009).

Through the exploratory factorial analysis, three essential factors were observed, which were conceived as strategic indicators of development (SACHS, 1986): indicator of urban development, indicator of industrial development / services and indicator of agricultural development. These indicators' characteristics are similar to the definitions of development have been identified (MARTINELLI; JOYAL, 2004; LLORENS, 2001; FRAGOSO, 2005; ALBUQUERQUE, 1998; OLIVARES; DALCOL, 2010).

By using the arithmetic mean of local development indicator for each cluster, it is shown that, on average, the cluster containing predominantly rural government regions is more developed than clusters with predominantly industrial regions of government. In addition, these results may contribute to the development of strategies for public management for local development (AUGIER; TEECE, 2008; SACHS, 1986).

This research proved that, considering the geographical delimitation of the State of São Paulo, the use of factor analysis is an excellent technique to diagnose the level of development for territories through the formation of indicators, being in agreement with similar studies involving territories of other states of Brazil (BARBOSA, 2013; ILHA et al., 2008; PEROBELLI et al., 1999).

\section{REFERENCES}

ALBUQUERQUE, Francisco. Desenvolvimento econômico local e distribuição do progresso técnico: uma resposta às exigências do ajuste estrutural. Fortaleza, BNB, 1998. AUGIER, M.; TEECE, D. J. Strategy as Evolution with Design: The Foundations of Dynamic Capabilities and the Role of Managers in the Economic System. Organization Studies, v. 29, n. 8-9, p. 1187-1208, 1 ago. 2008.

BARBOSA, F. Índice de desenvolvimento dos municípios da microrregião de Dourados-MS: uma aplicação da análise fatorial. 2013. 103 f. Dissertação (Mestrado em Agronegócio) - Faculdade de Administração, Ciências Contábeis e Economia da Universidade Federal da Grande Dourados, Dourados, 2013.

BEER, S. Diagnosing the system for organizations. London: John Wiley \& Sons, 1985.

BERTALANFFY, L. V. General system theory: foundations, development, applications. revised. 1. ed. New York: George Braziller, 1968.

FÁVERO, L. P.; BELFIORE, P.; SILVA, F. L.; CHAN; B. L. Análise de dados: modelagem multivariada para tomada de decisões. 3. ed. Rio de Janeiro: Elsevier, 2009. 
FRAGOSO, António. Desenvolvimento Participativo: uma sugestão de reformulação conceptual. Revista Portuguesa de Educação, v. 18, n. 1, p. 23-51, 2005.

FURTADO, C. Pequena introdução ao desenvolvimento: enfoque interdisciplinar. 1. ed. São Paulo: Companhia Editora Nacional, 1980.

GRZESZCZESZYN, G.; MACHADO, H. Public policy for the local development: the case of incentive to the furniture industries of Guarapuava, Paraná. Interações (Campo Grande), v. 11, n. 1, p. 81-92, 2010.

HADDAD, Paulo R. Capitais intangíveis e desenvolvimento regional. Revista de economia, v.35, n. 3, 2009.

HOWLETT, M.; RAMESH, M; PERL, A. Studying public policy: policy cycles \& policy subsystems. 3. ed. New York: Oxford University Press, 2009.

ILHA, A. S.; FREITAS, C. A.; CORONEL, D. A.; ALVES, F. D. O potencial de desenvolvimento dos municípios da Metade Sul do Rio Grande do Sul: Uma abordagem através da análise fatorial. Anais ..., v. 3, 2008.

INSTITUTO BRASILEIRO DE GEOGRAFIA E ESTATÍSITICA (IBGE). Disponível em: <http://www.ibge.gov.br/home/>. Acesso em 21 jan. 2016.

LATTIN, J.; CARROLL, J. D.; GREEN, P. E. Análise de dados multivariados. 1. ed. São Paulo: Cengage Learning, 2011.

LLORENS, F. A. Desenvolvimento econômico local: caminhos e desafios para uma nova agenda política. Tradução de Antônio R P. Braga. Rio de Janeiro: BNDES, 2001.

MARCH, J. G.; SIMON, H. A. Organizations. New York: Wiley, 1958.

MARTINELLI, Dante P.; JOYAL, André. Desenvolvimento local e o papel das pequenas e médias empresas: experiências brasileiras e canadenses. 1. ed. São Paulo: Manole, 2004.

MARTINS, R. VAZ, J. C. CALDAS, E. L. A gestão do desenvolvimento local no Brasil:(des) articulação de atores, instrumentos e território. Revista de Administração Pública, v. 44, n. 3, p. 559-590, 2010.

MATTOS, S.M.C.S. Arranjos produtivos locais como estratégia para o desenvolvimento local: o caso de Maracás. Sitientibus, Feira de Santana, n. 39, p 131-167, jul-dez. 2008.

OLIVARES, G.; DALCOL, P. Proposta de um sistema de indicadores para medir o grau de contribuição dos aglomerados produtivos para o desenvolvimento local e regional. Revista Brasileira de Gestão e Desenvolvimento Regional, v. 6, n. 2, 2010.

OLIVEIRA, G.; LIMA, J. Elementos endógenos do desenvolvimento regional: considerações sobre o papel da sociedade local no processo de desenvolvimento sustentável. Revista da FAE, Curitiba, v. 6, n. 2, p. 29-37, 2003.

OLIVEIRA, S.; MARTINEZ, R. Desenvolvimento Regional e Local fomentado pela participação e articulação de atores sociais. FACEF Pesquisa-Desenvolvimento e Gestão, v. 16, n. 3, 2013.

PEROBELLI, F. S.; OLIVEIRA, A. F.; NOVY, L. G. G.; FERREIRA, M. V. Planejamento regional e potenciais de desenvolvimento dos municípios de Minas Gerais na região em torno de Juiz de Fora: uma aplicação de análise fatorial. Nova Economia, v. 9, n. 1, 2013.

SACHS, I. Ecodesenvolvimento: crescer sem destruir. 1. ed. São Paulo: Vértice, 1986, 207 p.

SECCHI, L. Modelos organizacionais e reformas da administração pública. Revista de Administração Pública, Rio de Janeiro, v. 43, n. 2, p. 347-369, 2009.

WONG, C. Developing indicators to inform local economic development in England. Urban Studies, v. 39, n. 10, p. 1833-1863, 2002. 